\title{
Empirical Analysis on Optimizing Mixed Reform Ratio of Port and Shipping Companies in China
}

\author{
Bing Liao \\ Shanghai Maritime University, Shanghai, China \\ Email: excellentrabit@hotmail.com
}

How to cite this paper: Liao, B. (2020). Empirical Analysis on Optimizing Mixed Reform Ratio of Port and Shipping Companies in China. Modern Economy, 11, 848-856.

https://doi.org/10.4236/me.2020.114063

Received: February 28, 2020

Accepted: April 13, 2020

Published: April 16, 2020

Copyright ( 2020 by author(s) and Scientific Research Publishing Inc. This work is licensed under the Creative Commons Attribution International License (CC BY 4.0).

http://creativecommons.org/licenses/by/4.0/

\begin{abstract}
This paper takes China's port and shipping companies as an example to analyze the factors related to the proportion of mixed-change in the port industry, and whether it undertakes the social affairs is related to the equity ratio. By the empirical analysis, the non-state-owned shares of shipping companies are higher and the equity is more dispersed. For the more profitable port companies, they have lower intention for mixed reform. However, if the benefits of state-owned companies are too bad, private companies will not be interested. Only when the benefits of state-owned companies are within a certain range, for state-owned companies and private companies are both more willing to carry out mixed reform. The better the social benefits of the company, the better it will be to optimize the trend of the company's shareholding structure toward the non-state-owned shares.
\end{abstract}

\section{Keywords}

Port Industry, Mixed Ownership, Equity Ratio

\section{Introduction}

\subsection{Research Background}

The path logic of China's state-owned companies' mixed ownership reform is to optimize the ownership structure, then improve the corporate governance structure, and finally establish a modern company system to improve corporate performance. The core of the optimized equity structure is the proportion of equity ratio, especially the proportion of non-state-owned shares (Jiang \& $\mathrm{Xu}$, 2019). These stocks will have certain checks and balances on state-owned shares. The determination of the proportion of mixed reforms can provide theoretical 
basis and empirical reference for the reform of mixed ownership of state-owned companies.

Since the proportion of mixed reforms will determine whether the company can carry out mixed reforms, the proportion of mixed reforms is also related to the externalities of the companies, and is related to the social affairs (social responsibility) undertaken (Yang, 2019). This paper takes China's port and shipping companies as an example to analyze the port and aviation industry, what factors are related to the proportion of the change, and whether the social affairs undertaken by them are related to the proportion of equity?

\subsection{Research Method}

In the study of realistic problems, the change of the dependent variable is often affected by several important factors. Currently, it is necessary to use two or more influencing factors as independent variables to explain the change of the dependent variable. This is also known as multivariable regression. When there is a linear relationship between multiple independent and dependent variables, the regression analysis performed is multivariable regression (Weigler \& Slattum, 2001).

A multivariable linear regression model is used in this paper to study the relationship between the benefits of state-owned companies and their equity structure.

Multivariable linear regression model was applied in many fields for a history. It is seen as a very useful tool in detect the relationship of chosen variables by a potential theory based on massive data in a certain period (Tian, 2013). Only the chosen of variables is the key to a practical result (Zhang \& Yao, 2012). Then a robust test is necessary to verify the reliability (Aut, 2015).

\subsection{Research Structure}

For a multivariable linear regression model, first is to choose suitable data and variables to build the model according to the study aim of this paper, including dependant variable, independent variables and control variables.

Then we use the variables to build the suitable model for the problem and select required data according to the variables selected.

Finally, an authentic proof will be used to get test results, by analyzing the results to verify the relationship between the variables.

\section{Data Source and Design of Research Variables}

\subsection{Data Source}

This paper mainly studies the relationship between the proportion of non-state capital in China's port and shipping companies and the social benefits of the company. The selected indicators in this paper are the proportion of non-state-owned shares, social benefits, firm size, profitability, asset-liability ratio, shareholding ratio of the largest shareholder and growth. The study selected 
a total of 25 port and shipping companies, selected from 2016 to 2018, the reason why the selection of the past three years is mainly since the past three years is a key period for the reform of China's state-owned companies' mixed ownership reform. There is basically no "movement" in the state-owned port and shipping companies on mixed ownership before 2016, which has little significance for its research. In order to ensure the targeted and effective data, the data of the past three years has been adopted. The data is mainly collected by the authors by collecting and arranging the annual reports of the 25 listed companies.

\subsection{Design of Research Variables}

\subsubsection{Dependent Variable}

The shareholding structure is the ratio of shares of different nature to the total share capital. In China, it mainly refers to state shares, state-owned legal person shares and social public shares. This paper takes the proportion of non-state capital in the listed companies of port and shipping as the dependent variable. The calculation of this variable is 1 - (national stock + state-owned legal person stock)/total share capital.

\subsubsection{Independent Variable}

Tax refers to the relevant taxes and fees that should be borne by the business activities of the company. This article uses tax as a variable to measure social tax benefits. This article uses a variable of tax as a measure of social benefits, but considering the difficulty of obtaining data, this article has been simplified here, and only one indicator of tax is used to indicate social benefits. In addition, the tax here refers to taxes and surcharges. The reason for adopting this indicator is that income tax is not considered because the port industry is in a very sluggish situation in the past three years, especially for shipping companies, which are almost all in a loss situation and do not need to pay. Income tax, therefore tax indicators use taxes and additional indicators. After the reform of the camp, the value-added tax is exempted for offshore shipping companies, so the use of taxes and additional indicators is more practical.

\subsection{Control Variable}

The selection of control variables is based on firm size, financial leverage, ROE, shareholding ratio of the largest shareholder and growth as the controlling variable, with the aim of controlling the impact of the introduction of non-state-owned capital.

First, is the size of the company, this paper takes the natural logarithm of total assets as a variable to measure the size of the company.

Second, financial leverage, this article measures the level of financial leverage by asset-liability ratio. The asset-liability ratio is expressed by dividing the corporate liability by the total assets of the company. It can measure the ability of the company to use the creditor's funds for business activities. The larger the indicator, the higher the leverage of the company and it will be harder on future 
debt-paying ability of the company.

Third, ROE (Return of Equity), measure the company's ability to obtain net income from its own capital. It is shown that the higher the return on net assets, the stronger the ability of the company to gain profit.

Fourth, the shareholding ratio of the largest shareholder refers to the proportion of the shares held by the shareholders with the most shares in the listed company as a percentage of the total number of shares of the listed company. Recently, Wang Xin, Han Baoshan (Wang \& Han, 2018) and other scholars have found through empirical analysis that among the mixed ownership companies, the shareholding ratio of the largest shareholder has a certain influence on the company's performance.

Fifth, growth, this paper selects the operating income growth rate as a variable to measure the growth indicators of the company (Gao, 2019). The growth rate of operating income refers to the ratio of the increase in operating income of the company to the operating income of the previous year, and is an important indicator for evaluating the development capability and growth of the company.

Detail definition of each variable is shown in Table 1.

\section{Model Design and Authentic Proof}

\subsection{Model Design}

The following formula uses the actual data of the port industry to verify some of the conclusions in the theoretical model. This paper takes the proportion of non-state-owned capital as the dependent variable, social benefit (tax and surcharge) as the independent variable, company size, profitability, financial leverage, the proportion of the largest shareholder, the growth of the company, and the operational capacity of the company as the control variables. This paper uses a multivariable linear regression model to verify the relationship between the explanatory variables and interpreted variables under the collective effect of these variables.

Table 1. Definition of variables.

\begin{tabular}{cccc}
\hline Variable Type & Name & Code & Definition \\
\hline $\begin{array}{c}\text { Dependent } \\
\text { variable } \\
\begin{array}{c}\text { Independent } \\
\text { Variable }\end{array}\end{array}$ & $\begin{array}{c}\text { Equity ratio of } \\
\text { non-state-owned }\end{array}$ & NS & $\begin{array}{c}1-(\text { State-owned shares + State-owned legal } \\
\text { person shares)/total shares }\end{array}$ \\
& $\begin{array}{c}\text { Social benefit } \\
\text { Business scale }\end{array}$ & lnT & Natural logarithm of tax \\
Financial leverage & DA & Natural logarithm of total assets \\
Variable & Profitability & RA & Asset-liability ratio \\
& $\begin{array}{c}\text { Shareholding ratio of } \\
\text { the first shareholder }\end{array}$ & FR & Shareholding ratio of the first shareholder \\
& Growth & G & Growth rate of operating income \\
\hline
\end{tabular}


The empirical analysis model is as follows:

$$
N S_{i t}=\beta_{0}+\beta_{1} \ln T_{i t}+\beta_{2} \ln S_{i t}+\beta_{3} D A_{i t}+\beta_{4} R A_{i t}+\beta_{5} F R_{i t}+\beta_{6} G_{i t}+\varepsilon_{i t}
$$

In the above formula, $i$ represent 25 port companies, $t$ indicate year 2016 to 2018, $\varepsilon_{i t}$ indicates an error estimate. For $\beta_{1}$ is the main parameter to be estimated in this paper, the conclusions obtained in the theoretical model part of this paper can be supported by actual data.

\subsection{Descriptive Statistics}

According to the definition of variables, the statistical indicator values of the relevant variables are chosen out from annual report data of 25 port and shipping companies (see the attachment list) from the company websites between 2016-2018, shown in Table 2.

It can be seen from the above descriptive statistics that the average non-state-owned capital holding ratio of these 25 port and shipping companies is $47.23 \%$, and the highest is Changhang Phoenix Co., Ltd., and its non-state-owned capital holding ratio is as high as $98.72 \%$. The standard deviation is large, indicating that the proportion of non-state-owned shares of different companies is quite different. The difference in total assets and operating income of different companies is also large, indicating that there are significant differences in the business capabilities of different companies.

According to the specific analysis, the non-state-owned shares of shipping companies are higher and the equity is more dispersed. Among the shipping companies, Changhang Phoenix Co., Ltd. is a domestic shipping company, mainly engaged in dry bulk cargo. It is currently the largest shipping company in China, covering river, lake and coastal routes. Relatively strong in the whole process of logistics, relatively speaking, inland water transport, including container domestic trade, is a depressed area, so these companies are more motivated to mix and change, but for the port, it is generally profitable, so they are

Table 2. Descriptive Statistics on variables.

\begin{tabular}{ccccc}
\hline Variable Name & Average Value & Max Value & Min Values & Standard Deviation \\
\hline $\begin{array}{c}\text { Equity ratio of } \\
\text { non-state- owned }\end{array}$ & 47.23 & 98.72 & 12.36 & 21.57 \\
$\begin{array}{c}\text { Natural logarithm of tax } \\
\begin{array}{c}\text { Natural logarithm of total } \\
\text { assets }\end{array}\end{array}$ & 17.14 & 21.31 & 11.53 & 1.51 \\
ROE & 23.56 & 26.15 & 20.07 & 1.23 \\
$\begin{array}{c}\text { Assets/liabilities ratio } \\
\text { shareholding ratio of the } \\
\text { first shareholder }\end{array}$ & 4.80 & 17.92 & -44.19 & 6.94 \\
$\begin{array}{c}\text { Growth rate of operating } \\
\text { income }\end{array}$ & 18.24 & 89.19 & 6.34 & 15.53 \\
\end{tabular}

Resource: Annual report data of 25 port and shipping companies (see the attachment list) from the company websites between 2016-2018, according to the variables designed. 
not willing to allow private company to join for mixed reform ( $\mathrm{Hu}, 2018)$. Therefore, under normal circumstances, the enthusiasm of shipping companies for mixed reform is relatively higher. However, it should also be noted that if the benefits of state-owned companies are too bad, private companies will not be interested in joining the mixed reform team. Therefore, when the benefits of state-owned companies are within a certain range, for state-owned companies and private companies may be more willing to carry out mixed reform.

\subsection{Empirical Analysis}

This paper uses $\mathrm{R}$ software for data processing. The specific analysis process is as follows.

\subsubsection{Unit Root Test}

The test was carried out using the ADF-Fisher unit root test method. The original hypothesis is that there is a unit root, and the obtained values are 0.02075 and 0.01473 , respectively, which are less than 0.05 . It can be regarded as rejecting the null hypothesis at the $5 \%$ significance level, that is, the sequence is stable, and the multivariate analysis can be continued.

\subsubsection{Fixed Effect Regression Analysis}

Through the Hausman test, it is judged whether the model is a fixed effect model or a random effect model. The null hypothesis is a random effect model, and the calculated value is 0.007936 less than 0.01 , rejecting the null hypothesis, so the fixed effect model is chosen. The data was analyzed by $\mathrm{R}$ software, and the empirical results were obtained in Table 3.

Table 3. Empirical results.

\begin{tabular}{cc}
\hline Variable & NS \\
\hline $\ln T$ & $0.126^{* * *}$ \\
& $(0.000)$ \\
$\ln S$ & $1.078^{* *}$ \\
& $(0.010)$ \\
RA & $0.037^{* *}$ \\
& $(0.008)$ \\
DA & $-0.05^{*}$ \\
& $(0.038)$ \\
FR & $0.171^{* *}$ \\
& $(0.010)$ \\
G & $0.003^{*}$ \\
N & $(0.115)$ \\
R-Squared & 27 \\
\hline
\end{tabular}

Note: 1) Marked in the parentheses is the p value; 2$){ }^{* * *},{ }^{* *},{ }^{*}$ respectively indicate that the corresponding statistics are significant at the $1 \%, 5 \%$, and $10 \%$ levels. 
$p<0.01$, it shows that there is a positive correlation between the proportion of non-state-owned shares held by port and shipping companies and social benefits, and this positive impact is significant. In other words, the better the social benefits of the company, the better it will be to optimize the trend of the company's shareholding structure toward the non-state-owned shares. This also shows that more taxes a company pays, better the company's benefits, including both social and economic benefits. Currently, private companies and state-owned companies have some motivation to carry out mixed reforms. Of course, as mentioned above, the benefits need to be within a certain range, and the benefits are too good. State-owned companies do not want private companies to join (Yang, 2018). If the benefits are particularly bad, especially the losses are serious; private companies are reluctant to join the mixed reform. Since the research object is a listed company of the port and shipping industry, its benefits are generally not too bad, but because the port industry is not particularly prosperous in the past three years, its benefits will not be too good, just in a relatively balanced position. Therefore, the conclusions of this study are very consistent with the actual situation.

\subsubsection{Robustness Test}

The robustness test further tests whether the results of the empirical analysis are robust or vary with changes in parameter settings. If the parameters change, the sign and saliency change, indicating that the result is not robust. The robustness test of the model can be divided into two types: one is the robustness test of the measurement method, that is, the other is a relatively reliable measurement method. If it is the panel data, the GMM can be used for the robustness test; the other is the measurement data. The usual method of robustness testing is to change data and replace variables in the model with other variables.

This paper conducts a robustness test by changing the indicators of the control variables in the model. For the convenience of statistical processing, the company's total assets are changed to the number of employees (EN), and the transformed model is as follows:

$$
N S_{i t}=\beta_{0}+\beta_{1} \ln T_{i t}+\beta_{2} E N_{i t}+\beta_{3} D A_{i t}+\beta_{4} R A_{i t}+\beta_{5} F R_{i t}+\beta_{6} G_{i t}+\varepsilon_{i t}
$$

Here $\beta_{2}$ is the main estimated parameter. If $\beta_{2}>0$ and there is still a positive correlation between the proportion of non-state-owned shares held by state-owned companies and the size of company; and if the significance of the results has not changed, the empirical results described above are robust. Here $i$ represent 25 companies, $t$ represent year 2016 to 2018, $\varepsilon_{i t}$ indicates an error estimate. Regression of the replaced data with $\mathrm{R}$ software, the results are shown in Table 4.

Thus, the empirical results support the theoretical conclusions. Within a certain scope, with the increase of social benefits, more private capital can be entered in the process of mixed ownership reform. 
Table 4. Results of robustness test.

\begin{tabular}{cc}
\hline Variable & NS \\
\hline lnT & $0.143^{* * *}$ \\
& $(0.001)$ \\
EN & $1.241^{* *}$ \\
& $(0.007)$ \\
RA & $0.017^{* *}$ \\
& $(0.004)$ \\
DA & $-0.035^{*}$ \\
& $(0.04)$ \\
FR & $0.202^{* *}$ \\
& $(0.01)$ \\
G & 0.003 \\
N & $(0.128)$ \\
R-Squared & 27 \\
\end{tabular}

Note: 1) Marked in the parentheses is the $\mathrm{p}$ value; 2$)^{* * *},{ }^{* *},{ }^{*}$ respectively indicate that the corresponding statistics are significant at the $1 \%, 5 \%$, and $10 \%$ levels. Empirical results indicate, $\beta_{2}=0.172>0$, and $p<0.01$, which is consistent with previous results in terms of symbol and significance. It shows that there is still a positive correlation between the proportion of non-state-owned shares and social benefits, and the impact is significant, which proves that the previous empirical results are robust.

\section{Conclusion}

The non-state-owned shares of shipping companies are higher and the equity is more dispersed. For the more profitable port companies, they have lower intention for mixed reform. However, if the benefits of state-owned companies are too bad, private companies will not be interested. Only when the benefits of state-owned companies are within a certain range, the state-owned companies and private companies are both more willing to carry out mixed reform. The better the social benefits of the company, the better it will be to optimize the trend of the company's shareholding structure toward the non-state-owned shares.

\section{Conflicts of Interest}

The author declares no conflicts of interest regarding the publication of this paper.

\section{Refzerences}

Aut, K. V. (2015). FastRCS: FastRCS Robust Fit of Multivariable Linear Regression Model.

Gao, X. H. (2019). Research on the Necessity of State-Owned Companies to Implement Subsidy Supervision. Modern Business.

Hu, Z. H. (2018). Deepening the Reform of State-Owned Companies with the Help of the Principle of Competitive Neutrality. People's Forum, No. 12, 84-86.

Jiang, L., \& Xu, J. R. (2019). Exploring the Reform Path of Mixed Ownership of State-Owned Companies. Economic Reference.

Tian, S. (2013). Mass Appraisal of Property Tax Base Based on Multivariate Linear Re- 
gression-Empirical Study on Four Districts of Jinan. Paris: Atlantis Press. https://doi.org/10.2991/icetis-13.2013.254

Wang, X., \& Han, B. S. (2018). Analysis on the Governance Effect of Equity Structure in Mixed Ownership Companies. Economic Reform, No. 6, 125-131.

Weigler, B. J., \& Slattum, M. M. (2001). Multivariable Regression Analysis and Other Findings from the 1999 Joint ASLAP/ACLAM Economic Survey of Laboratory Animal Veterinarians. Contemporary Topics in Laboratory Animal Science, 40, 9-13.

Yang, Q. (2019). Mixed Reform of State-Owned Companies: To Prevent the Loss of State Assets, to Avoid Harming the Legitimate Rights and Interests of Private Capital. China Company News, Comprehensive Version.

Yang, R. L. (2018). The Evolution and Reflection of the Reform Logic and Practice of State-Owned Companies . Journal of People's University of China, No. 5, 50-62.

Zhang, X. F., \& Yao, L. (2012). Comprehensive Measure and Influential Factors of Fragility of Commercial Bank System in China. Lanzhou, Gansu: 2012 Fifth International Conference on Business Intelligence and Financial Engineering (BIFE).

https://doi.org/10.1109/BIFE.2012.54 